\title{
Evaluation of Some Insecticides against Tomato Leaf Miner, Tuta absoluta (Meyrick) (Gelechiidae: Lepidoptera) Under Laboratory and Glasshouse Conditions
}

\author{
Tadele Shiberu* and Emana Getu \\ Department of Zoological Sciences, Addis Ababa University, Ethiopia
}

Submission: March 16, 2017; Published: May 30, 2017

"Corresponding author: Tadele Shiberu, Addis Ababa University, College of Natural and Computational Sciences, Department of Zoological Sciences, Ethiopia, Email: tshiberu@yahoo.com

\begin{abstract}
The tomato leafminer Tuta absoluta (Meyrick) (Lepidoptera: Gelechiidae), is a native devastating pest, particularly to the tomato Lycopersicon esculentum. The present study was carried out to determine the efficacy of different insecticides at different concentrations against the larvae of Tuta absoluta on tomato in laboratory and glasshouse. Percent mortalities were recorded after 24, 48 and 72 hours of application in the laboratory and after 3 and 5 days in the glasshouse. The results showed that the tested insecticides were significantly $(\mathrm{P}<0.01)$ different in relation to pest mortality than untreated check, while after 72 hours of treatment application percent mortalities were obtained by Coragen $200 \mathrm{SC}^{\mathrm{TM}}$ proved most effective and gave (95.55\%) followed by the mixture of Prove 1.9E. ${ }^{\mathrm{TM}}$ and Levo 2.4SL ${ }^{\mathrm{TM}}(80.0 \%)$ while Levo $2.4 \mathrm{SL}^{\mathrm{TM}}$ alone gave lowest percent mortality $37.78 \%$. Similarly, in glasshouse also Coragen $200 \mathrm{~S}^{\mathrm{TM}} \mathrm{C}$ proved most effective and gave (89.68\%) after 3 days of treatments application. Therefore, the mixture of Prove 1.9 E.C $\mathrm{C}^{\mathrm{TM}}$ and Levo $2.4 \mathrm{SL}^{\mathrm{TM}}$ was used for the management of T. absoluta in addition to Coragen 200SCTM under glasshouse conditions.
\end{abstract}

Keywords: Efficacy; Mortality; Tuta absoluta; Concentration; Insecticides; Coragen 200SC ${ }^{\mathrm{TM}}$; Levo 2.4SL $\mathrm{T}^{\mathrm{TM}}$; Prove 1.9E.C. ${ }^{\mathrm{TM}}$

\section{Introduction}

Tomato leafminer, Tuta absoluta (Meyrick) (Gelechiidae: Lepidoptera) originating from South America, was considered in its origin distribution area as a significant tomato insect pest $[1,2]$, it is not only to the intensity of its attack but also to its occurrence during all crop cycle [3]. Frequently the tomato leaf miner, T. absoluta attack it in sufficient numbers to cause damage each year that feed on the leaves and fruits of this plant. It is an invasive pest causing severe loss for tomato production in many countries either in open field or green houses [4]. If no control measures are taken, then the pest can cause up to $80-100 \%$ yield losses by attacking leaves, flowers, stems and especially fruits [5].

T. absoluta introduction in Ethiopia is rather recent. Its first report is recorded in the Eastern Shawa of Rift valley, Ethiopia in 2012 [6] and then distributed to most parts of the country. Chemical insecticide control has been the first strategy adopted in the newly invaded areas, alternative control measures are being investigated [7]. In the case of T. absoluta, the need for alternative control methods is strengthened by the development of resistance to insecticides by the pest $[8,9]$ as well as the side effects of pesticides on beneficial arthropods $[10,11]$. Insecticide control against T. absoluta has been developed and widely applied in different countries such as several South American, Asia and Africa including Ethiopia, using the new active ingredient which is likely to be the core of the integrated pest management (IPM) programme is Chlorantraniliprole (Coragen 200SCTM). At present there are no other alternative insecticides to control $T$. absoluta in Ethiopia.

Therefore, two new other insecticides from the new chemistries, which were relatively safer to human and environment, i.e. Emamectin benzoate (Prove 1.9E.C. ${ }^{\mathrm{TM}}$ ), Prosuler Oxymatrin (Levo 2.4SL ${ }^{\mathrm{TM}}$ ), the mixture of Prosuler Oxymatrin 
and Emamectin benzoate (Levo 2.4SL $\mathrm{SL}^{\mathrm{TM}}+$ Prove 1.9E.C ${ }^{\mathrm{TM}}$ ), and Chlorantraniliprole (Coragen 200SC ${ }^{\mathrm{TM}}$ ), were tested on tomato crop infested by T. absoluta in the laboratory and glasshouse in years of 2015/16-2016/17. Hence, the objective of this study was to determine the appropriate concentration and screening new insecticides against T. absoluta.

\section{Materials and Methods}

\section{Experiments under laboratory and glasshouse conditions}

Laboratory and glasshouse studies were under taken to evaluate the newly introduced Prosuler Oxymatrin (Levo 2.4SL ${ }^{\mathrm{TM}}$ ) and Emamectin Benzoate (Prove 1.9E.C $\mathrm{C}^{\mathrm{TM}}$ ) insecticides in three different concentrations $(1 \mathrm{ml}, 2 \mathrm{ml}$ and $3 \mathrm{ml} /$ liter $)$. The experiments were conducted at a temperature of $24 \pm 2{ }^{\circ} \mathrm{C}$ and $50 \pm 5 \%$ RH for a period of $72 \mathrm{hrs}$ in the laboratory. Larvae were inserted in a Petri dish within the leaves and provided with coated cotton moist that was kept as fresh leaves of tomato that had collected from the glasshouse. Seventy two hours latter larval percent mortalities were counted. The best performing, insecticides of each concentration were selected for subsequent glasshouse experiments.

In glasshouse 24 pots were prepared and filled with compost, loam soil and sand soil in the ratio of 1:1:2, respectively. A Pot having a height of $25 \mathrm{~cm}$ and a diameter of $20 \mathrm{~cm}$ was used. The experiment was arranged in a randomized completely block design (RCBD) in three replications. Purposefully the door and

\section{Result and Discussion}

\section{Effect of insecticides against T. absoluta under laboratory}

Table 2: Mean percent mortality of $T$. absoluta caused by tested insecticide under laboratory Conditions.

\begin{tabular}{|c|c|c|c|c|c|}
\hline \multirow[t]{2}{*}{ S.N } & \multirow[t]{2}{*}{ Treatments } & \multirow[t]{2}{*}{ Conc. } & \multicolumn{3}{|c|}{ Mean Percent Mortality } \\
\hline & & & After $24 \mathrm{hrs}$ & After $48 \mathrm{hrs}$ & After $72 \mathrm{hrs}$ \\
\hline 1 & Emamectin benzoate (Prove 1.9E.C $\mathrm{C}^{\mathrm{TM}}$ ) & $\begin{array}{l}1 \% \\
2 \% \\
3 \%\end{array}$ & $\begin{array}{l}31.11^{\mathrm{cd}} \\
37.78^{\mathrm{c}} \\
37.78^{\mathrm{c}}\end{array}$ & $\begin{array}{l}42.22^{\mathrm{de}} \\
44.45^{\mathrm{cd}} \\
46.67^{\mathrm{c}}\end{array}$ & $\begin{array}{l}51.11^{\mathrm{cd}} \\
57.78^{\mathrm{c}} \\
60.00^{\mathrm{c}}\end{array}$ \\
\hline 2 & Prosuler oxymatrin (Levo $2.4 \mathrm{SL}^{\mathrm{TM}}$ ) & $\begin{array}{l}1 \% \\
2 \% \\
3 \%\end{array}$ & $\begin{array}{l}22.22^{\mathrm{d}} \\
35.55^{\mathrm{c}} \\
35.55^{\mathrm{c}}\end{array}$ & $\begin{array}{l}33.33^{\mathrm{e}} \\
35.55^{\mathrm{de}} \\
37.78^{\mathrm{cde}}\end{array}$ & $\begin{array}{r}37.78^{\mathrm{e}} \\
42.22^{\mathrm{de}} \\
42.22^{\mathrm{de}}\end{array}$ \\
\hline $\begin{array}{l}3 \\
4 \\
5\end{array}$ & $\begin{array}{c}\text { Prove 1.9 E.C }{ }^{\mathrm{TM}}+\text { Levo } 2.4 \mathrm{SL}^{\mathrm{TM}} \\
\text { Chlorantraniliprole (Coragen } 200 \mathrm{SC}^{\mathrm{TM}} \text { ) } \\
\text { Control }\end{array}$ & $\begin{array}{c}2: 2 \% \\
1 \%\end{array}$ & $\begin{array}{l}62.22^{\mathrm{b}} \\
93.33^{\mathrm{a}} \\
0.00^{\mathrm{e}}\end{array}$ & $\begin{array}{l}77.78^{\mathrm{b}} \\
95.55^{\mathrm{a}} \\
0.00^{\mathrm{f}}\end{array}$ & $\begin{array}{l}80.00^{\mathrm{b}} \\
95.55^{\mathrm{a}} \\
0.00^{\mathrm{f}}\end{array}$ \\
\hline & $\begin{array}{l}\text { LSD at } 0.01 \\
\text { CV (\%) } \\
\text { SE } \pm\end{array}$ & & $\begin{array}{l}12.79 \\
13.96 \\
5.36\end{array}$ & $\begin{array}{c}12.68 \\
12.26 \\
5.31\end{array}$ & $\begin{array}{c}12.27 \\
11.07 \\
5.15\end{array}$ \\
\hline
\end{tabular}

Note: Means with the same letter(s) are not significantly different for each other. All treatment effects were highly significant at $p<0.01$ (DMRT). 
The data on the effectiveness of insecticides against $T$. absoluta revealed that highly significant $(\mathrm{P}<0.01)$ difference among treatments in laboratory after treatment exposure of 72 hours (Table 2). The results showed that the insecticide Coragen 200SCTM, Prove 1.9E. $\mathrm{C}^{\mathrm{TM}}$ ) and the mixture of Prove 1.9E. $\mathrm{C}^{\mathrm{TM}}+$ Levo $2.4 \mathrm{SL}^{\mathrm{TM}}$ were found to be highly significant $(\mathrm{P}<0.01)$ superior over the control $95.55 \%$ mortality followed by the mixture of Prove 1.9E. $\mathrm{C}^{\mathrm{TM}}$ and Levo 2.4STML 2\% concentration $80.0 \%$ mortality. The lowest mortality percent recorded at $1 \%$ concentration of Levo $2.4 \mathrm{SL}^{\mathrm{TM}}, 22.22 \%$ followed by Prove $1.9 \mathrm{E}$. $\mathrm{C}^{\mathrm{TM}}, 31.11 \%$ were observed after 24 hours treatment application while they were found to be highly significant $(\mathrm{p}<0.01)$ and superior over the control (Table 2).

The mortality of T. absoluta was higher after 48 and 72 hours of insecticidal application as compared with 24 hours because of the lethal influence gradually the insect physiology which culminated in the highest control. The best performance by Chlorantraniliprole (Coragen 200SC ${ }^{\mathrm{TM}}$ ) among the insecticides could be due to their desirable mode of action that effectively blocked a physiological mechanism in the target insect right 48 hours of application and after 72 hours mortality reached the highest percent mortality followed by the mixture of Emamectin benzoate (Prove 1.9E.C ${ }^{\mathrm{TM}}$ ) and Prosuler oxymatrin (Levo $2.4 \mathrm{SL}^{\mathrm{TM}}$ ). Our findings indicated that increase in mortality rate in all the treatments in concentration and time dependent manner.

Limited information is available regarding the efficacy of new chemistry on tomato leaf miner, $T$ absoluta, anyway the results of this study are in conformity with Emmanouil [13] who reported that the toxicity of the insecticides was determined on second instar larvae using commercial formulations of the insecticides clorantraniliprole, Prosuler Oxymatrin and emamectin benzoate. He also reported that mortality was estimated after 72 hours of exposure and results were subjected to prohibit analysis. The insecticides clorantraniliprole and the mixture of emamectin benzoate and Prosuler Oxymatrin exhibited high larvicide activity. Emmanouil [13] also reported that experiments under laboratory indicated that emamectin benzoate insecticide exhibited high larvacidal activity over LC95, while our results showed low larvicidal effects (60\%) in the laboratory.

\section{Effect of insecticides against $T$, absoluta under glasshouse}

The data on the effectiveness of insecticides sprayed to overcome the T. absoluta revealed a highly significant $(\mathrm{P}<0.01)$ difference among treatments in glasshouse (Table 3). The presented data are pertaining to mean percent reduction of $T$. absoluta revealed that, among all the treatments the Coragen $200 \mathrm{SC}^{\mathrm{TM}}$ gave the highest mortality $89.68(74.56 \%)$ percent mortality followed by the mixture of Prove 1.9E. $\mathrm{C}^{\mathrm{TM}}+$ Levo $2.4 \mathrm{SL}^{\mathrm{TM}}$ insecticides 78.94(62.73\%) percent mortality. Prove 1.9E. $\mathrm{C}^{\mathrm{TM}}$ and Levo $2.4 \mathrm{SL}^{\mathrm{TM}}$ were recorded to be $39.81(39.09 \%)$ and $25.28(30.12 \%)$ significantly inferior in efficacy against T. absoluta within five days of application, respectively. All insecticides gave the mean percent reduction of T. absoluta and significantly higher than control treatments.

Table 3: Mean percent mortality of tested insecticides against tomato leafminer, $T$. absoluta Under glasshouse conditions.

\begin{tabular}{|c|c|c|c|c|c|}
\hline \multirow[t]{2}{*}{ S.No. } & \multirow[t]{2}{*}{ Treatments } & \multirow[t]{2}{*}{ Conc $(\%)$} & \multicolumn{3}{|c|}{ Mean Percent Mortality } \\
\hline & & & 1 day & 3 day & 5 day \\
\hline 1 & Emamectin benzoate (Prove 1.9 E.C ${ }^{\mathrm{TM}}$ ) & $2 \%$ & $30.55(33.51)^{\mathrm{b}}$ & $34.26(35.69)^{\mathrm{c}}$ & $39.81(39.09)^{\mathrm{b}}$ \\
\hline 2 & Prosuler oxymatrin (Levo $2.4 \mathrm{SL}^{\mathrm{TM}}$ ) & $2 \%$ & $17.49(24.67)^{c}$ & $22.25(28.04)^{\mathrm{d}}$ & $25.28(30.12)^{c}$ \\
\hline 3 & Prove 1.9E.C+Levo 2.4SL ${ }^{\mathrm{TM}}$ & $2: 2 \%$ & $51.52(45.87)^{\mathrm{bc}}$ & $74.77(60.14)^{\mathrm{ab}}$ & $78.94(62.73)^{\mathrm{a}}$ \\
\hline 4 & Chlorantraniliprole (Coragen $200 \mathrm{SC}^{\mathrm{TM}}$ ) & $1 \%$ & $76.59(61.21)^{\mathrm{a}}$ & $89.68(74.56)^{\mathrm{a}}$ & $89.68(74.56)^{\mathrm{a}}$ \\
\hline 5 & Control & & $3.33(6.14)^{d}$ & $7.50(13.04)^{\mathrm{c}}$ & $7.50(13.04)^{c}$ \\
\hline LSD at 0.01 & & & 12.42 & 24.7 & 17.83 \\
\hline CV $(\%)$ & & & 12.63 & 19.73 & 13.49 \\
\hline $\mathrm{SE} \pm$ & & & 4.53 & 9.02 & 6.51 \\
\hline
\end{tabular}

Note: Means with the same letter(s) are not significantly different for each other. All treatment effects were highly significant at $p<0.01$ (DMRT).

Throughout the experiments, the mixture of Emamectin Benzoate and Prosuler Oxymatrin products proved more efficacy suppressed T. absoluta larval populations followed by Emamectin Benzoate alone. Indeed, several authors reported the performance of Emamectin Benzoate product against several insects, for example, Seal [14], reported the efficacy of emamectin benzoate at various rates in reducing the densities of the melon thrips, Thrips palmi adults and larvae. Stanley et al.
[15] reported the high acute toxicity of emamectin benzoate to Helicoverpa armigera under laboratory conditions.

It was reported by several authors the active ingredient of Emamectin benzoate has a high potency against a broad spectrum of lepidopterous pests with an efficacy potent against certain armyworm species [16]. Cook et al. [17] conducted field and laboratory trials on cotton and soybean for the control of the beet armyworm Spodoptera exigua (Hübner) and the fall 
armyworm Spodoptera frugiperda using emamectin benzoate demonstrated the good efficacy of tested products compared with the control. But we obtained low percent mortality of $T$. absoluta larvae under laboratory and glasshouse conditions.

The efficacies of spraying using mixtures of natural products and synthetic chemicals for the control of the pests are crucial. Indeed, insecticides that work in synergy when mixed together are an avenue to explore in T. absoluta control. We agreed that the work of Bielza et al. [18], they have been proposed that pesticides mixtures with different modes of action may delay the onset of resistance developing in pest populations. However, some problems need to be considered when two or more insecticides are mixed together especially Phytotoxicity [19].

Management of resistance to prevent or delay the development of resistance to an insecticide and cross resistance to additional insecticides is necessary for increasing the chance of insecticide control of T. absoluta. Our glasshouse and laboratory studies suggest the good performance of the tested compounds Chlorantraniliprole (Coragen 200SC ${ }^{\mathrm{TM}}$ ) followed by (a mixture of Emamectin Benzonate and Prosuler Oxymatrin were important for the managment of tomato leafminer, T. Absoluta [20-23].

\section{Conclusion and Recommendation}

T. absoluta has been a serious pest of tomatoes in Ethiopia since 2012. These studies clearly indicated the efficacious of chemicals such as Chlorantraniliprole (Coragen $200 \mathrm{SC}^{\mathrm{TM}}$ ) and a mixture of Emamectin benzoate and Prosuler oxymatrin (Prove 1.9 E. $\mathrm{C}^{\mathrm{TM}}$ and Levo $2.4 \mathrm{SL}^{\mathrm{TM}}$ ) showed good efficacy in controlling T. absoluta larvae, they can be used in conjunction with chemical products and integrated pest management. Therefore, it was recommended that Coragen $200 \mathrm{SC}^{\mathrm{TM}}$ and a mixture of Prove 1.9 E. $\mathrm{C}^{\mathrm{TM}}+$ Levo $2.4 \mathrm{SL}^{\mathrm{TM}}$ are used as a management option of $T$. absoluta as components of integrated pest management.

\section{References}

1. Lobos E, Occhionero M, Werenitzky D, Fernandez J, Gonzalez LM, et al (2013) Optimization of a trap for Tuta absoluta Meyrick (Lepidoptera: Gelechiidae) and trials to determine the effectiveness of mass trapping Neotropical Entomology 42(5): 448-457.

2. Leite GLD, Picanço M, Guedes RNC, Zanuncio JC (2001) Role of plant age in the resistance of Lycopersicum hirsutum f. glabratum to the tomato leafminer Tuta absoluta (Lepidoptera: Gelichiidae). Sci Hort 89: 103-113.

3. Oliveira ACRD, Veloso VDRS, Barros RG, Fernandes PM, Souza ERBD (2008) Captura de Tuta absoluta (Meyrick) (Lepidoptera: Gelichiidae) comarmadilha luminosa na cultura do tomateiro tutrado. Pesqui Agropecu Trop 38(3): 153-157.

4. Khidr AA, Gaffar SA, Maha SN, Taman AA, Fathia AS (2013) New approaches for controlling tomato leafminer, Tuta absoluta (Meyrick) in tomato fields in Egypt. Egypt J Agric Res 91 (1): 335-345.

5. Öztemiz S (2012) The tomato leafminer [(Tuta absoluta Meyrick (Lepidoptera: Gelechiidae) and it's biological control. KSU J Nat Sci 15(4): 47-57.
6. Gashawbeza A, Abiy F (2013) Occurrence of a new leaf mining and fruit boring moth of tomato, Tuta absoluta (Meyric) (Lepidoptera: Gelechiidae) in Ethiopia. Pest Management J of Ethiopia 16: 57-61.

7. Cagnotti CL, Viscarret MM, Riquelme MB, Botto EN, Carabajal LZ, et al. (2012) Effects of X-rays on Tuta absoluta for use in inherited sterility programmes. J Pest Sci 85(4): 413-421.

8. Haddi K, Berger M, Bielza P, Cifuentes D, Field LM, et al. (2012) Identification of mutations associated with pyrethroid resistance in the voltagegated sodium channel of the tomato leaf miner (Tuta absoluta). Insect Biochem. Mol Biol 42(7): 506-513.

9. Gontijo PC, Picanc OMC, Pereira EJG, Martins JC, Chediak M, et al. (2013) Spatial and temporal variation in the control failure likelihood of the tomato leaf miner, Tuta absoluta. Ann Appl Bio 162(1): 50-59.

10. Arno J, Gabarra R (2011) Side effects of selected insecticides on the Tuta absoluta (Lepidoptera: Gelechiidae) predators Macrolophus pygmaeus and Nesidiocoris tenuis (Hemiptera: Miridae). J Pest Sci 84(4): 513-520.

11. Biondi A, Desneux N, Siscaro G, Zappala L (2012) Using organic certified rather than synthetic pesticides may not be safer for biological control agents: selectivity and side effects of 14 pesticides on the predator Orius laevigatus. Chemosphere 87(7): 803-812.

12. SAS (2009) Statistical Analysis System Software. Ver. 9.1. SAS Institute InC., Carry.

13. Emmanouil R (2011) Determination of baseline toxicity of insecticides to Tuta absoluta.

14. Seal DR (2005) Management of melon thrips, Thrips palmi Karny (Thysanoptera: Thripidae) using various chemicals. Proc Fla State Hort Soc 118: 119-124.

15. Stanley J, Chandrasekaran, Regupathy A (2009) Basesline toxicity of emamectin and spinosad to Helicoverpa armigera (Lepidoptera : Noctuidae) for resistance monitoring. Entomologi 39(5): 321-325.

16. Jansson RK, Brown R, Cartwright B, Cox D, Dunbar DB, et al. (1996) Emamectin benzoate: a novel avermectin derivate for control of lepidopterous pests. Proceedings: the management of Diamonback Moths and other crucifers pests. Chemical control 171-177. Entomology. Cornell University.

17. Cook DR, Leonard BR, Gore J (2004) Field and laboratory performance of novel insecticides against armyworms (Lepidoptera: Noctuidae). Florida Entomologist 87(4): 433-439.

18. Bielza P, Fernández E, Graválos C, Albellán J (2009) Carbamates synergize the toxicity of acrinathrin in resistant western flower thrips (Thysanoptera: Thripidae). J Econ Entomol 102(1): 393-397.

19. Mohamed B, Lobna H (2012) Management of Tuta absoluta (Lepidoptera, Gelechiidae) with Insecticides on Tomatoes. InsecticidesPest Engineering. pp. 33-354.

20. Abbott WS (1925) A method of computing the effectiveness of an insecticide. J Econ Entomol 18(2): 265-267.

21. Cocco A (2013) Potential of mass trapping for T. absoluta management in greenhouse tomato crops using light and pheromone traps. IOBCWPRS Bulletin 80, pp. 319-324.

22. EPPO/IOBC/FAO/NEPPO Joint International Symposium on management of Tuta absoluta (tomato borer, Lepidoptera: Gelechiidae) in collaboration with the IRAC and IBMA Agadir, Morocco.

23. Gomez KA, Gomez AA (1984) Statistical procedures for Agricultural Research. $\left(2^{\text {nd }} e d n\right)$, John Wiley and Sons Inc., New York, USA. 
This work is licensed under Creative Commons Attribution 4.0 License

DOI: 10.19080/ARTOAJ.2017.07.555711

\section{Your next submission with Juniper Publishers} will reach you the below assets

- Quality Editorial service

- Swift Peer Review

- Reprints availability

- E-prints Service

- Manuscript Podcast for convenient understanding

- Global attainment for your research

- Manuscript accessibility in different formats ( Pdf, E-pub, Full Text, Audio)

- Unceasing customer service

Track the below URL for one-step submission https://juniperpublishers.com/online-submission.php 